Araștırma Makalesi / Research Article

Moleküler Biyoloji ve Genetik /

Moleculer Biology and Genetic

DOI: $10.21597 /$ jist.538260
Iğdır Üniversitesi Fen Bilimleri Enstitüsü Dergisi, 9(3): 1657-1665, 2019

Journal of the Institute of Science and Technology, 9(3): 1657-1665, 2019

\title{
Studies of Anticancer Activity of Beta-carotene, Alpha-tocopherol and Ascorbic acid in SH-SY5Y Neuroblastoma Cells
}

\section{Ekrem DARENDELIOĞLLU ${ }^{1 *}$}

\begin{abstract}
Neuroblastoma (NB; SH-SY5Y cells) is important characteristic of the most widespread cancer in children after leukaemia and brain cancer. Discovery of new treatment approaches are required for NB disease. Epidemiological studies have demonstrated that different types of antioxidants are associated with decreased cancer and neurodegenerative diseases. Fruits and vegetables have a plenty source of Beta-carotene (BC), Alpha-tocopherol (vit E) and Ascorbic acid (vit C) that have potent free radicals scavenging actions and inhibitory properties to biochemical oxidation. $\mathrm{BC}$, vit $\mathrm{E}$ and vit $\mathrm{C}$ increase the intracellular reactive oxygen species (ROS) generation and encourages cell apoptosis. It was found that these antioxidants resulted in an increase in the malondialdehyde (MDA) (marker of lipid peroxidation; LPO) and ROS levels at high concentration suggesting it behaves as a prooxidant in this study. The outcomes obviously indicated that studies of SH-SY5Y with dose-dependent BC, vit $\mathrm{E}$ and vit $\mathrm{C}$ results in oxidative damage through an increase in ROS and LPO generation and the expression of apoptotic marker caspase-3. These consequences find out additional evidences that these antioxidants could be involved in the process of apoptosis for new therapy in NB cells.
\end{abstract}

Keywords: Beta-carotene, alpha-tocopherol, ascorbic acid, apoptosis, SH-SY5Y

\section{SH-SY5Y Nöroblastom Hücrelerinde Beta-karoten, Alfa-tokoferol ve Askorbik asidin Antikanser Etkilerinin Araştırılması}

ÖZET: Nöroblastom (NB; SH-SY5Y hücreleri), lösemi ve beyin kanserinden sonra özellikle çocuklarda en yaygın görülen kanser türü olduğu için çalışılması tercih edilmiştir. NB için yeni tedavi yaklaşımları gerekmektedir. Bazı ülkelerde yapılan epidemiyolojik çalışmalar, farklı tipte antioksidanların kanser ve nörodejeneratif hastalıkların azalması ile ilişkili olduğunu göstermektedir. Meyve ve sebzeler, biyokimyasal oksidasyonu engelleyici etkileri ve serbest radikalleri yakalama özellikleri olan bol miktarda Beta-karoten (BC), Alfa-tokoferol (vit E) ve Askorbik asit (vit $\mathrm{C}$ ) içermektedir. $\mathrm{BC}$, vit $\mathrm{E}$ ve vit $\mathrm{C}$ hücre içi ROS oluşumunu arttırarak apoptozu teşvik edebilmektedir. Bazı çalışmalarda belirtildiği üzere bu antioksidanların yüksek konsantrasyonlarda, LPO ve ROS oluşumunda bir artışa yol açtığ 1 ve prooksidan olarak davrandığ gösterilmektedir. Bu çalışmanın sonucunda elde edilen veriler, BC, vit E ve vit C'nin SH-SY5Y NB hücreleri üzerindeki etkisi doza bağımlı olarak ROS ve LPO üretiminde bir artışa sebep olarak oksidatif hasara ve devamında apoptotik kaspaz-3 proteini ekspresyonunda artışa neden olduğunu açıkça göstermektedir. Elde edilen sonuçlar, bu çalışmada etkisi araştırılan antioksidanların NB hücreleri için apoptoz sürecinde yeni tedavi yaklaşımları açısından değerlendirilebileceğini göstermektedir.

Anahtar Kelimeler: Beta-karoten, alfa-tokoferol, askorbik asit, apoptoz, SH-SY5Y

\footnotetext{
${ }^{1}$ Ekrem DARENDELİĞLUU (Orcid ID: 0000-0002-0630-4086), Bingöl University, Faculty of Arts and Sciences, Moleculer Biology and Genetic, Bingöl-Turkey

*Sorumlu Yazar / Corresponding Author: Ekrem DARENDELİOĞLU, e-mail: edarendelioglu@bingol.edu.tr
} 


\section{INTRODUCTION}

Neuroblastoma (NB) is the paediatric tumour of the central nervous system (CNS) that originates from the neural tissues. (Maris, 2010; Ricciardi et al., 2017). NB is prevalently found in infants and children, after leukaemia and brain cancer. It is also used in neuroprotection research to develop new approaches for the therapy and prevention of CNS diseases (Agholme et al., 2010; Koriyama et al., 2015). $\mathrm{NB}$ is reported to be a biological and clinical disease; therefore, medicinal strategies to NB rely on the level of the disorders, age and biological causes (Maris et al., 2007; Jiang et al., 2011). In view of the aforementioned reasons, research on investigating efficient and novel class biochemical compounds and leads are needed along with new treatment approaches for NB.

Epidemiological studies revealed that Mediterranean district has remarkably decreased death rate (Grosso et al., 2013). The Mediterranean diet (MD) is shown to be linked with reduced case of some diseases related to cardiovascular system, cancer and neurodegenerative disorders. The protective effect was credited to antioxidant and biologically active compound content of vegetables and fruits (Renaud et al., 1995). MD contains high intake of many of vegetables and their products with high beta-carotene (BC), alpha-tocopherol (vit E) and ascorbic acid (vit C) content that have potent free radicals scavenging activities (Byers and Perry, 1992). The role of antioxidant molecules and enzymes is to tune of the amount of reactive oxygen species that are required in the redox regulation of the cell cycle and of apoptosis (Kahl et al., 2004; Bayindir et al., 2018; Temel et al., 2018).

$\mathrm{BC}$ is vitamin A precursor which is found in fruits and vegetables (Lin et al., 2009). Preceding in vivo and in vitro studies revealed effective role of $\mathrm{BC}$ in decreasing the occurrence rate of epithelial cell cancers that is responsible for more than $90 \%$ of all cancer deaths (Pastorino et al., 1987). High dietary consumption of fruits and vegetables rich in BC has been reported to be linked with decreased risk of cancer at variety of organ sites, particularly in the lung (Ziegler, 1989; Van Poppel and Goldbohm, 1995). BC has also shown to control cell viability and apoptosis in numerous cancer cell lines that contain lung, melanoma, colon and leukemia cancer cells lines (Bogenmann, 1996; Hazuka et al., 1990; Palozza et al., 2002; Palozza et al., 2003). In addition to these, role of $\mathrm{BC}$ in reducing the incidence of lung metastasis by B16F-10 melanoma cells has also been reported (Pradeep and Kuttan, 2003).

Vit $\mathrm{E}$ is a lipid-soluble vitamin found in various nutrients and has many physiologic functions (Bjomeboe et al., 1990). Vit E may prevent against cancer by several mechanisms (Knekt et al., 1991). Similar to Vit C, Vit E is reported to inhibit the formation of $\mathrm{N}$-nitroso compounds. Vit $\mathrm{E}$ also prevents reduction against selenium (Horvath and Ip, 1983) and prevents poly-unsaturated fatty acids in lipid membranes from oxidative injury (Horrobin, 1991). Vit E has been reported as key lipidsoluble radical scavenging antioxidant in cell membranes (Burton et al., 1983; Pryor, 1991; Kolankaya et al., 2002).

Vit $\mathrm{C}$ is the commonly found water soluble anti-oxidant compound in mammals (Frei et al., 1989). The role of Vit $C$ as a nutrient in preventing cancer was reported by numerous mechanisms (Henson et al., 1991). In addition, it was shown to involve in the production of collagen and in inhibiting the reaction of $\mathrm{N}$ nitroso compound formation. Beneficial effects of vit $\mathrm{C}$ and the carotenoids on immune system were studied demonstrating their role in decreasing cancer risk by inducing tumour surveillance by the immune system (Bendich, 1989; Henson et al., 1991; Ringer et al., 1991). 
The focus of this study was to investigate the anti-cancer effect of $\mathrm{BC}$, vit $\mathrm{C}$ and vit $\mathrm{E}$ on SH-SY5Y neuroblastoma cells in vitro and reveal the anti-cancer mechanism of the antioxidants. This was achieved by cell viability test, ROS and LPO assays, immunohistochemical staining and propidium iodide experiments.

\section{MATERIALS AND METHODS}

\section{Cell Culture}

Human neuroblostoma cells SH-SY5Y (ATCC ${ }^{\circledR}$ CRL-2266 ${ }^{\mathrm{TM}}$ ) were cultured in complete medium (DMEM) that include $10 \%$ fetal bovine serum, $1 \%$ antibiotics mixture of penicilin and streptomycin. SH-SY5Y at passage 4-8 were preferred in the research. The $\mathrm{SH}$ SY5Y was cultured in humidified incubator with $5 \% \mathrm{CO}_{2}$ and controlled every other day. $\mathrm{SH}-$ SY5Y were controlled for contamination using commercially available mycoplasma kit.

\section{Experimental Grouping}

Human SH-SY5Y cells were grouped into four sets. In the first set (control group), the cells were cultured in the presence of DMEM without anti-oxidants. In BC group, cells were cultured in the presence of BC $(60 \mu \mathrm{g} / \mathrm{ml})$ in DMEM for $24 \mathrm{~h}$. In third group, cells were cultured in the presence of vit E $(60 \mu \mathrm{g} / \mathrm{ml})$ in DMEM for $24 \mathrm{~h}$. In vit $\mathrm{C}$ group, cells were cultured in the presence of vit C $(60 \mu \mathrm{g} / \mathrm{ml})$ in DMEM for $24 \mathrm{~h}$.

\section{Cell Viability Assay}

Water Soluble Tetrazolium-1 (WST-1) assay kit was used to investigate the effects of $\mathrm{BC}$, vit $\mathrm{E}$ and vit $\mathrm{C}$ on SH-SY5Y human neuroblostoma cells. Experiments were carried out according to the procedure provided by the supplier. Initially the cells were seeded in 96well plate. Subsequent to that, SH-SY5Y was cultured with different doses of $\mathrm{BC}$, vit $\mathrm{E}$ and vit $\mathrm{C}$ between 15, 30 and $60 \mu \mathrm{g} / \mathrm{ml}$. After that, $5 \mu \mathrm{l}$ of WST-1 component was added into each well. Following that, the reaction mixture was cultured for $4 \mathrm{~h}$ and the absorbance of each well was measured at $450 \mathrm{~nm}$ (reference: $630 \mathrm{~nm}$ ) by SpectraMax Plus 384 Microplate Reader.

\section{Intracellular ROS Detection}

The amount of ROS generated by BC, vit $\mathrm{E}$ and vit $\mathrm{C}$ was measured by 2',7'dichlorodihydrofluorescin diacetate (DCFHDA). The SH-SY5Y was cultured as explained in experimental grouping. Approximately, $10^{6}$ cells were cultured with $2 \mu \mathrm{M}$ DCFH-DA at $37^{\circ}$ $\mathrm{C}$ for $1 \mathrm{~h}$. Fluorescence intensities were measured by spectrofluorometer using exitation and emmission wavelengths of $485 \mathrm{~nm}$ and $525 \mathrm{~nm}$ respectively.

\section{Lipid Peroxidation Assay}

The SH-SY5Y was cultured as explained in experimental grouping. Following that, LPO assay was carried out as described: SH-SY5Y was cultured and centrifuged at $2500 \mathrm{rpm}$. After that, the cells were mixed with $70 \%$ w/v trichloroacetic acid and $1 \mathrm{~mL}$ of thiobarbituric acid $(0.8 \% \mathrm{w} / \mathrm{v})$. Later, the mixture was incubated at $95{ }^{\circ} \mathrm{C}$ for $30 \mathrm{~min}$. Following incubating in ice for $5 \mathrm{~min}$, the mixture was centrifuged at $15000 \mathrm{rpm}$ for $10 \mathrm{~min}$. The absorbance was measured at $532 \mathrm{~nm}$ in 96-well plate by SpectraMax Plus 384 Microplate Reader. Malondialdehyde (MDA) bis was used for standard graph preparation. The levels of MDA for each sample were calculated and expressed as $\mu \mathrm{M}$ (Smith et al., 1982).

\section{Propidium Iodide Staining for Apoptosis}

Cells were cultured and harvested in 96well plate. Later, cells were cultured as described in experimental grouping. Then, cells were washed with PBS twice. Propidium iodide was added to each well and cells were imaged by inverted microscope with fluorescence attachment (Olympus, JAPAN). 
Evaluation

of

Apoptosis

Immunohistochemical Method

Cells were cultured and harvested as explained in experimental grouping. Immunohistochemical method was performed according to the procedures supplied by UltraVision LP Large Volume Detection System HRP Polymer kit, hydrogen peroxide block and DAP substrate kit (Thermo Scientific, USA) and mouse monoclonal caspase-3 p11 antibody (diluted at 1:500; Santa Cruz Biotechnology, USA).

\section{Statistical Analysis}

All of the experiments carried out during the research were repeated three times. The results were statistically analysed by GraphPad Prism 5.0 and were assessed by one-way ANOVA Newman-Keuls Post-Hoc Test; $\mathrm{p}<0.05$ was considered as significant.

\section{RESULTS AND DISCUSSION}

\section{Cell Viability}

The effects of three different antioxidants in SH-SY5Y human neuroblostoma cells were investigated by cytotoxicity assay. The viability of $\mathrm{BC}$, vit $\mathrm{E}$ and vit $\mathrm{C}$ on SH-SY5Y cell line was studied by WST-1 assay. The results of representative experiments are shown (Figure 1). In general, all antioxidants tested within this study decreased cell viability at concentrations of $60 \mu \mathrm{g} / \mathrm{ml}$ when compared to control cells. As demonstrated in figure 1, high antioxidants levels significantly decreased the viability of SH-SY5Y $(p<0.01)$. These observations indicate that $\mathrm{BC}$, vit $\mathrm{E}$ and vit $\mathrm{C}$ are effective for killing the cancer cells.

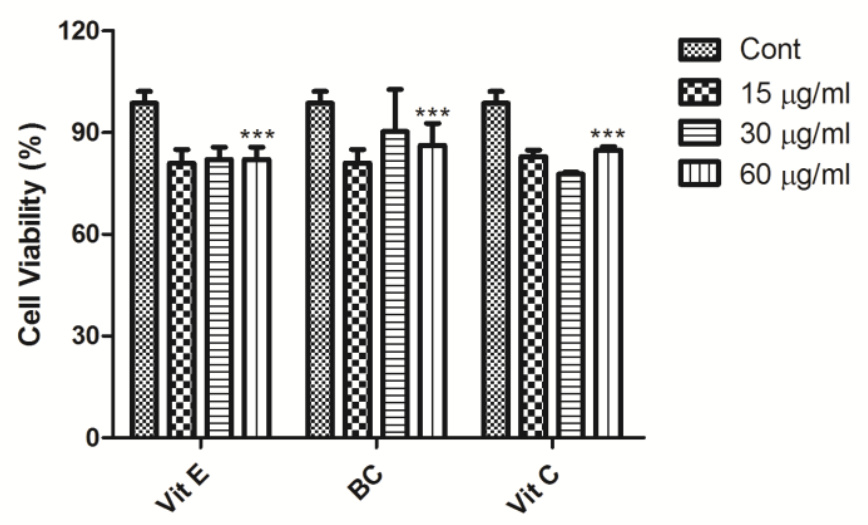

Figure 1. The effect of BC, vit E, vit C on SH-SY5Y cell line. Cell viability (\%) was investigated by WST-1 assay. The data were expressed by mean $\pm \operatorname{SEM}(n \geq 3) .{ }^{* * *} \mathrm{p}<0.01$ Cont vs all antioxidants

\section{Intracellular ROS and LPO Analysis}

To determine whether these antioxidants could effect ROS production, a well-known ROS assay was preferred. The results demonstrated that as indicated in figure $2 \mathrm{~A}$, ROS production increased in comparison with non-treated neuroblastoma cancer cells $(\mathrm{p}<0.05)$. The most abundant lipid peroxide is malondialdehyde (MDA). LPO assay was used to evaluate oxidative stress through calculating the amount of MDA. The results demonstrated a dose dependent increase in MDA generation. As given in figure $2 \mathrm{~B}$, the data suggested significant differences $(p<0.01)$ in MDA generation at 60 $\mu \mathrm{g} / \mathrm{ml}$ compared to the control. Overall, BC, vit $\mathrm{E}$ and vit $\mathrm{C}$ increased amount of ROS and LPO and this could result in an increase in oxidative stress and apoptosis in dose dependent manner in neuroblastoma cells. 
A

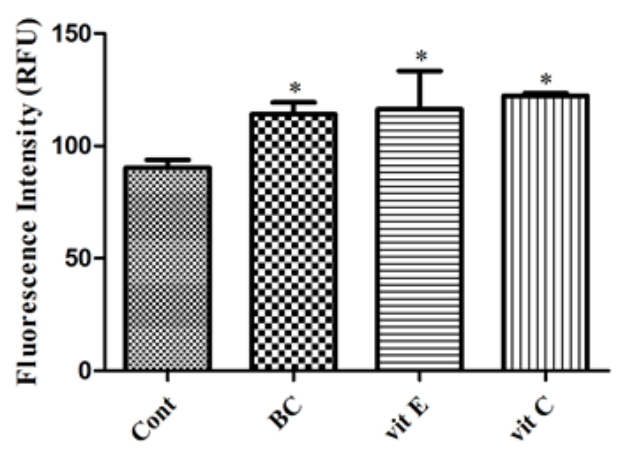

B

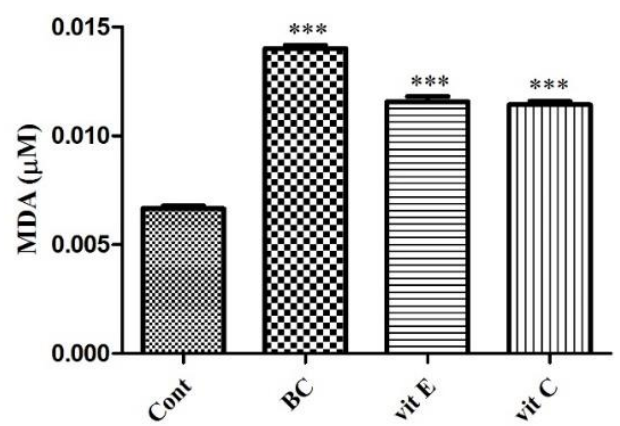

Figure 2. The effect of BC, vit E, vit C on ROS (A) generation and LPO levels (B) in SH-SY5Y cell line. Cells were exposed to antioxidants. Data were presented by mean $\pm \operatorname{SEM}(n=3)$

\section{Apoptotic Staining}

Apoptotic staining of cellular nuclei was carried out by propidium iodide as a cell death marker. The apoptotic cells are characterized by the typical nuclear modifications. In apoptotic stages, the nuclei of the cells was shrunk. Apoptotic cells are less coloured as well as shown in (Figure 3).

\section{Caspase 3 Staining}

To further confirm that the cell death was resulted from the induction of the apoptotic cascade, cas-3 staining was performed for the active form of cas-3. The results indicate the presence of cas-3 positive represented by black dots shown by arrows. This further demonstrates that the effect of these antioxidants is through apoptotic pathway. The expression levels of cas3 were also upregulated by $\mathrm{BC}$, vit $\mathrm{E}$ and vit $\mathrm{C}$. These results provide further evidence that these antioxidants could play an apoptotic role in cancer cells.

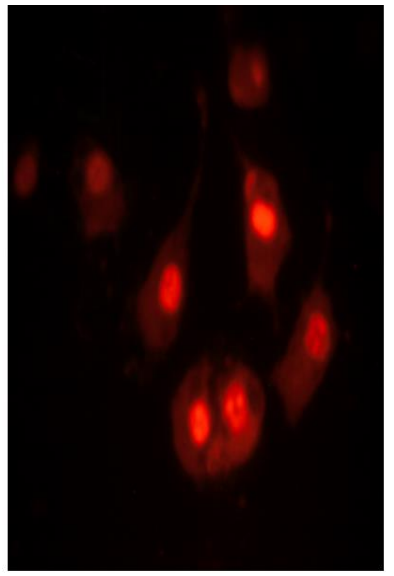

Cont

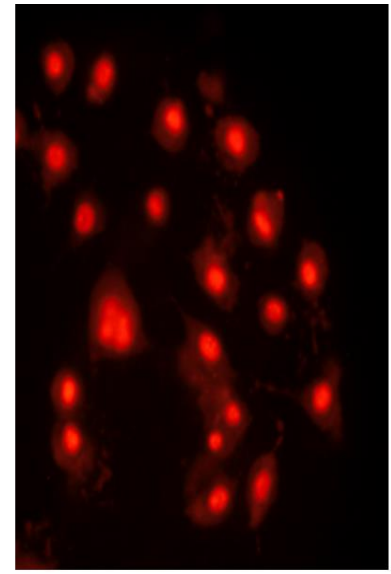

BC

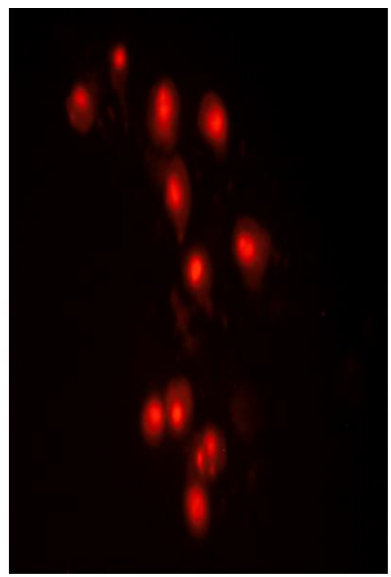

vit $\mathbf{E}$

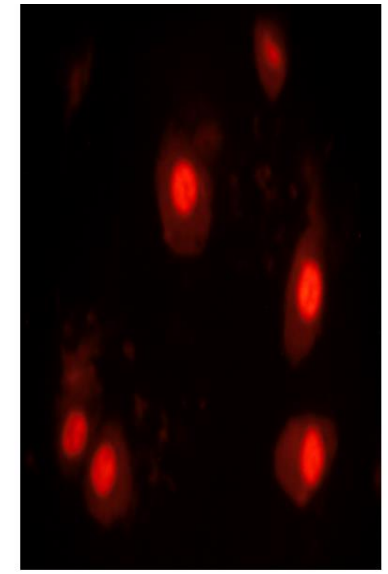

vit $\mathbf{C}$

Figure 3. The effect of BC, vit E, vit C $(60 \mu \mathrm{g} / \mathrm{ml})$ compared to the control $(0 \mu \mathrm{g} / \mathrm{ml})$ on apoptosis evidenced by propidium staining 


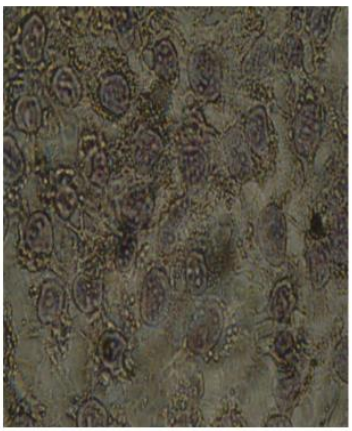

Cont

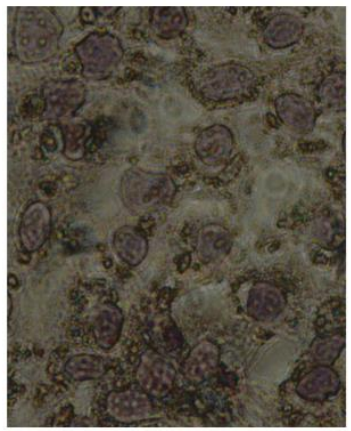

BC

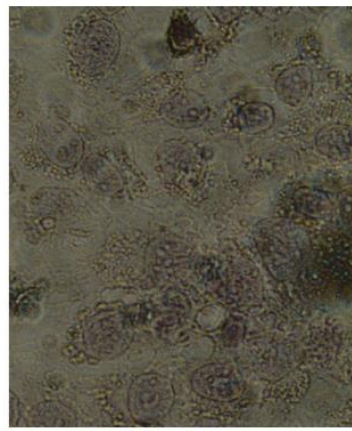

vit $\mathbf{E}$

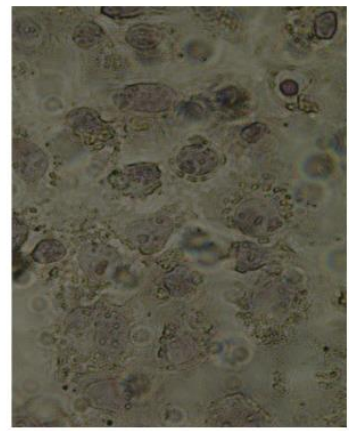

vit C

Figure 4. The effect $\mathrm{BC}$, vit $\mathrm{E}$, vit $\mathrm{C}$ compared to the control on apoptosis related active cas-3 in $\mathrm{SH}$ SY5Y

Neuroblastoma is important characteristic of the most widespread cancer in children (Maris, 2010; Agholme et al., 2010; Koriyama et al., 2015; Ricciardi et al., 2017). Studies on determination of efficient and novel class compounds along with development of new therapy approaches are required for the treatment of the neuroblastoma cancer. Association of different types of antioxidant molecules and enzymes with reduced incidence of cancer and neurodegenerative disorders are reported in various studies (Byers and Perry, 1992; Bayindir et al., 2018; Temel et al., 2018).

$\mathrm{BC}$ is shown to be linked with a decreased risk several cancers including lung, colon and leukaemia cancers controlling cell viability and apoptosis (Palozza et al., 2002; Middha et al., 2018; Khurana et al., 2018; Kavalappa et al., 2019). In a study carried out by Cui and his friends it was reported that $\mathrm{BC}$ can behave as either antioxidant or prooxidant, reliant on the redox potential of the organ or tissue in which it acts (Cui et al., 2007). A series of research show the role of $\mathrm{BC}$ on controlling intracellular redox status and its effect on apoptotic pathways. The carotenoids are shown to act as antioxidants at low concentrations reducing amount of free radical produced while, act as prooxidant at relatively high concentrations (Cui et al., 2007). In a study carried out by Cui et al., (2007), it was reported that $\mathrm{BC}$ increases the ROS level which has key role in the cell proliferation regulation and apoptosis. One of the aims of this research was investigating the effect of $\mathrm{BC}$ on ROS generation and apoptosis in NB cells. The results demonstrated that $\mathrm{BC}$ resulted in an alteration in the LPO and ROS levels at high concentration suggesting it acts as a prooxidant in this study.

The role of vit $\mathrm{C}$ in protecting and suppression of carcinogenic compounds has been well studied (Mazerand and Cock, 2019). In addition to this effect, cancer preventing effect of the vit $\mathrm{C}$ that is independent of this mechanism was also reported. The studies demonstrated that vit $\mathrm{C}$ has the capability to reduce the rate of tumour development in mouse skin cancer models (Shamberger, 1972). As stated in Sinnberg (2014), high-dose vit C destroys cancer cells both in vitro and in vivo. This cytotoxic effect is resulted by the extracellular generation of ROS leading to making high dose vit $\mathrm{C}$ a prooxidative anticancer agent. In this research the results supported this information as high concentrations of vit $\mathrm{C}$ increased ROS and LPO levels.

Vit $\mathrm{E}$ is reported to inhibit formation of carcinogenic molecules in the stomach sharing the same properties as Vit C (Abraham et al., 2018). Pham-Huy et al., (2008) reported that antioxidant properties of vit $\mathrm{E}$ is stemmed from the prevention against LPO. The studies on Vit E demonstrated its protective role against various cancers including colon, prostate and breast cancers. In this research the results supported 
this information as high concentrations of vit $\mathrm{E}$ increased ROS and LPO generations.

Recent studies have suggested that dosedependent antioxidants molecules increase LPO levels and oxidative stress and induces apoptosis (Darendelioglu et al., 2016; Tartik et al., 2016). ROS is associated with in loss of mitochondria membranes potentials which are important for opening the mitochondria membranes permeability transition pore (MPTP). Subsequently, release of some key proapoptotic proteins (cyt $c$ ) from the mitochondria trigger the cas signalling pathway (Steed and Tyagi, 2011). Activated cas-3 results in apoptosis (Tyagi et al., 2005).

\section{CONCLUSION}

The anticancer effect of $\mathrm{BC}$, vit $\mathrm{C}$ and vit $\mathrm{E}$ on SH-SY5Y neuroblastoma cells were evaluated within this study. This was carried out by investigating the effect of these antioxidants on cell viability, production of ROS and LPO and their relationship with apoptosis. The results conclude that treatment of SH-SY5Y Neuroblastoma cells with the antioxidants resulted in oxidative stress via an increase in ROS level and cas-3 expression.

\section{REFERENCES}

Abraham A, Kattoor AJ, Saldeen T, Mehta JL, 2018. Vitamin $\mathrm{E}$ and its anticancer effects. Critical reviews in food science and nutrition, 1-8.

Agholme L, Lindström T, Kågedal K, Marcusson, J, Hallbeck M, 2010. An in vitro model for neuroscience: differentiation of SH-SY5Y cells into cells with morphological and biochemical characteristics of mature neurons. Journal of Alzheimer's disease, 20(4): 1069-1082.

Bayindir S, Ayna A, Temel Y, Ciftci M, 2018. The synthesis of new oxindoles as analogs of natural product 3, 3'-bis (indolyl) oxindole and in vitro evaluation of the enzyme activity of G6PD and 6PGD. Turkish Journal of Chemistry, 42(2), 332-345.
Bendich A, 1989. Carotenoids and the immune response. The Journal of Nutrition, 119: 11215.

Bjorneboe A, Bjørneboe GEA, Drevon CA, 1990. Absorption, transport and distribution of vitamin E. The Journal of Nutrition, 120(3): 233-242.

Bogenmann E, 1996. A metastatic neuroblastoma model in SCID mice. International Journal of Cancer, 67(3): 379-385.

Burton GW, Joyce A, Ingold KU, 1983. Is vitamin E the only lipid-soluble, chain-breaking antioxidant in human blood plasma and erythrocyte membranes. Archives of Biochemistry and Biophysics, 221(1): 281290.

Byers T, Perry G, 1992. Dietary carotenes, vitamin $\mathrm{C}$, and vitamin $\mathrm{E}$ as protective antioxidants in human cancers. Annual Review of Nutrition, 12(1): 139-159.

Cui Y, Lu Z, Bai L, Shi Z, Zhao WE, Zhao B, 2007. $\beta$-Carotene induces apoptosis and up-regulates peroxisome proliferator-activated receptor $\gamma$ expression and reactive oxygen species production in MCF-7 cancer cells. European Journal of Cancer, 43(17): 2590-2601.

Darendelioglu E, Aykutoglu G, Tartik M, Baydas G, 2016. Turkish propolis protects human endothelial cells in vitro from homocysteineinduced apoptosis. Actahistochemica, 118(4): 369-376.

Frei B, England L, Ames BN, 1989. Ascorbate is an outstanding antioxidant in human blood plasma. Proceedings of the National Academy of Sciences, 86(16): 6377-6381.

Grosso G, Buscemi S, Galvano F, Mistretta A, Marventano S, La Vela V, Biondi A, 2013. Mediterranean diet and cancer: epidemiological evidence and mechanism of selected aspects. BMC surgery, 13(2): 14.

Hazuka MB, Edwards-Prasad J, Newman F, Kinzie JJ, Prasad KN, 1990. Beta-carotene induces morphological differentiation and decreases adenylate cyclase activity in melanoma cells in culture. Journal of the American College of Nutrition, 9(2): 143-149. 
Henson DE, Block G, Levine M, 1991. Ascorbic acid: biologic functions and relation to cancer. JNCI: Journal of the National Cancer Institute, 83(8): 547-550.

Horrobin DF, 1991. Is the main problem in free radical damage caused by radiation, oxygen and other toxins the loss of membrane essential fatty acids rather than the accumulation of toxic materials. Medical hypotheses, 35(1): 23-26.

Horvath PM, Ip C, 1983. Synergistic effect of vitamin $\mathrm{E}$ and selenium in the chemoprevention of mammary carcinogenesis in rats. Cancer research, 43(11): 5335-5341.

Ip C, 1982. Dietary vitamin E intake and mammary carcinogenesis in rats. Carcinogenesis, 3(12): 1453-1456.

Jämsä A, Hasslund K, Cowburn RF, Bäckström A, Vasänge $M, 2004$. The retinoic acid and brainderived neurotrophic factor differentiated $\mathrm{SH}-$ SY5Y cell line as a model for Alzheimer's disease-like tau phosphorylation. Biochemical and Biophysical Research Communications, 319(3): 993-1000.

Jiang M, Stanke J, Lahti JM, 2011. The connections between neural crest development and neuroblastoma.In Current topics in developmental biology. Academic Press, 94: 77-127.

Kahl R, Kampkötter A, Wätjen W, Chovolou Y, 2004. Antioxidant enzymes and apoptosis. Drug metabolism reviews, 36(3-4): 747-762.

Kavalappa YP, Rudresh DU, Gopal SS, Shivarudrappa AH, Stephen NM, Rangiah K, Ponesakki G, 2019. $\beta$-carotene isolated from the marine red alga, Gracillaria sp. potently attenuates the growth of human hepatocellular carcinoma (HepG2) cells by modulating multiple molecular pathways. Journal of Functional Foods, 52, 165-176.

Knekt P, Aromaa A, Maatela J, Aaran RK, Nikkari T, Hakama M, Teppo L, 1991. Vitamin E and cancer prevention. The American Journal of Clinical Nutrition, 53(1): 283-286.
Kolankaya D, Selmanoğlu G, Sorkun K, Salih B, 2002. Protective effects of Turkish propolis on alcohol-induced serum lipid changes and liver injury in male rats. Food Chemistry, 78(2): 213-217.

Koriyama Y, Furukawa A, Muramatsu M, Takino JI., Takeuchi M, 2015. Glyceraldehyde caused Alzheimer's disease-like alterations in diagnostic marker levels in SH-SY5Y human neuroblastoma cells. Scientific Reports, 5: 13313.

Lin J, Cook NR, Albert C, Zaharris E, Gaziano JM, Van Denburgh M, Manson JE, 2009. Vitamins $\mathrm{C}$ and $\mathrm{E}$ and beta carotene supplementation and cancer risk: a randomized controlled trial. Journal of the National Cancer Institute, 101(1): 14-23.

Maris JM, 2010. Recent advances in neuroblastoma. New England Journal of Medicine, 362(23): 2202-2211.

Maris JM, Hogarty MD, Bagatell R, Cohn SL, 2007. Neuroblastoma.The Lancet 369 (9579): 2106-2120.

Mazerand C, Cock IE, 2019. An Examination of the Antibacterial, Antifungal, Anti-Giardial and Anticancer Properties of Buchanania obovata Engl. Fruit Extracts. Pharmacognosy Communications, 9(1).

Middha P, Weinstein SJ, Männistö S, Albanes D, Mondul AM, 2018. $\quad \beta$-Carotene Supplementation and Lung Cancer Incidence in the Alpha-Tocopherol, Beta-Carotene Cancer Prevention Study: The Role of Tar and Nicotine. Nicotine \& Tobacco Research.

Palozza P, Serini S, Maggiano N, Angelini M, Boninsegna A, Di Nicuolo F, Calviello G, 2002. Induction of cell cycle arrest and apoptosis in human colon adenocarcinoma cell lines by $\beta$-carotene through down-regulation of cyclin A and Bcl-2 family proteins. Carcinogenesis, 23(1): 11-18. 
Palozza P, Serini S, Torsello A, Di Nicuolo F, Piccioni E, Ubaldi V, Calviello G, 2003. $\beta$ Carotene regulates NF- $\kappa B$ DNA-binding activity by a redox mechanism in human leukemia and colon adenocarcinoma cells. The Journal of Nutrition, 133(2): 381-388.

Pastorino U, Pisani P, Berrino F, Andreoli C, Barbieri A, Costa A, Marubini E, 1987. Vitamin A and female lung cancer: A casecontrol study on plasma and diet. Nutrition and cancer, 10(4): 171-179

Pham-Huy LA, He H, Pham-Huy C, 2008. Free radicals, antioxidants in disease and health. International Journal of Biomedical Science: IJBS, 4(2): 89.

Pradeep CR, Kuttan G, 2003. Effect of [beta]carotene on the inhibition of lung metastasis in mice. Phytomedicine, 10(2/3): 159.

Pryor WA, 1991. Can vitamin E protect humans against the pathological effects of ozone in smog? The American Journal of Clinical Nutrition, 53(3): 702-722.

Renaud S, De Lorgeril M, Delaye J, Guidollet J, Jacquard F, Mamelle N, Toubol P, 1995. Cretan Mediterranean diet for prevention of coronary heart disease. The American Journal of Clinical Nutrition, 61(6): 1360-1367.

Ricciardi V, Portaccio M, Piccolella S, Manti L, Pacifico S, Lepore M, 2017. Study of SHSY5Y cancer cell response to treatment with polyphenol extracts using FT-IR spectroscopy. Biosensors, 7(4): 57.

Ringer TV, De Loof MJ, Winterrowd GE, Francom SF, Gaylor SK, Ryan JA, Hughes GS, 1991. Beta-carotene's effects on serum lipoproteins and immunologic indices in humans. The American Journal of Clinical Nutrition, 53(3): 688-694.

Shamberger RJ, 1972. Increase of peroxidation in carcinogenesis. Journal of the National Cancer Institute, 48(5): 1491-1497.
Sinnberg T, Noor S, Venturelli S, Berger A, Schuler P, Garbe C, Busch C, 2014. The ROS-induced cytotoxicity of ascorbate is attenuated by hypoxia and HIF-1alpha in the NCI 60 cancer cell lines. Journal of Cellular and Molecular Medicine, 18(3): 530-541.

Smith MT, Thor H, Hartzell P, Orrenius S, 1982. The measurement of lipid peroxidation in isolated hepatocytes. Biochemical

Pharmacology, 31(1): 19-26.

Steed MM, Tyagi SC, 2011. Mechanisms of cardiovascular remodeling in hyperhomocysteinemia. Antioxidants \& redox signaling, 15(7): 1927-1943.

Tartik M, Darendelioglu E, Aykutoglu G, Baydas G, 2016. Turkish propolis supresses MCF-7 cell death induced by homocysteine. Biomedicine \& Pharmacotherapy, 82: 704-712.

Temel Y, Ayna A, Hamdi Shafeeq I, Ciftci M, 2018. In vitro effects of some antibiotics on glucose6-phosphate dehydrogenase from rat (Rattus norvegicus) erythrocyte. Drug and chemical toxicology, 1-5.

Tyagi N, Sedoris KC, Steed M, Ovechkin AV, Moshal KS, Tyagi SC, 2005. Mechanisms of homocysteine-induced oxidative stress. American Journal of Physiology-Heart and Circulatory Physiology, 289(6): 26492656.

Van Poppel G, Goldbohm RA, 1995. Epidemiologic evidence for beta-carotene and cancer prevention. The American Journal of Clinical Nutrition, 62(6): 1393-1402.

Ziegler RG, 1989. A review of epidemiologic evidence that carotenoids reduce the risk of cancer. The Journal of Nutrition, 119(1): 116122. 